\title{
Dissection of Herzberg's Two-Factor Theory to Predict Job Satisfaction: Empirical Evidence from the Telecommunication Industry of Pakistan
}

\section{Seeham Yousaf*}

\begin{abstract}
Herzberg's motivation theory is one of the most widely studied motivation theories. This theory is also known as the two-factor or dual-factor theory. The premise of Frederick Herzberg's theory is that the concept of motivation is divided into two aspects: hygiene and motivators. There is no denying of the fact that the theory of Herzberg of employee motivation is very pertinent in explaining the work behaviors of organizational employees. Nevertheless, this theory attracts substantial criticism from its critics who strongly contended that there is no need to revive the original theory as it lacks substantial influence in explaining employee motivation. Taking this notion forward, this study aims to test the fundamental factors that are of six hygiene factors (extrinsic factors), and five motivators (intrinsic factors) that affect the job satisfaction of front line employees (FLEs). In doing so, this study moves beyond the dichotomy of these two factors and examine the pertinence of underlying factors that can directly influence the employee job satisfaction. The FLEs are the faces that represent organizations, as they directly interact with the customers at their business units. The study analyzes the data by applying a structured equation model on a survey sample of 284 employees, constituting of business managers and executives in both metropolitan and non-metropolitan areas in telecommunication industry of Pakistan. This research reveals positive and direct relationship of five of the underlying factors (money, relationship with peers, relationship with supervisors, work itself and recognition) with job satisfaction.
\end{abstract}

Keywords: Herzberg's theory, job satisfaction, telecommunication, front line employees

JEL Classification: M12, J53, K23, K31.

\footnotetext{
${ }^{*}$ Senior Teaching Fellow, Lahore School of Economics, Lahore, Pakistan.
} 


\section{Introduction}

A positive attitude of employees is essential for an organization's success (Khan, Abbas, \& Zaki, 2017), as they are the most valuable resource for any firm. They can build or destroy its corporate and business standing by affecting its overall profitability (Elnaga \& Imran, 2013). Organizations in the service sector heavily rely on their frontline employees' (FLE) services in order to maintain successful communication in terms of twoway information flow. Likewise, FLEs through service encounters are also a major source of transferring substantial external information to firms (Santos-Vijande, López-Sánchez, \& Rudd, 2016).

Frontline service employees are the most crucial employees as they are the representatives of service sector firms. The FLEs must follow standardized operating procedures at the service encounters in order to convey high service quality that is always reliable (Maria Stock, 2017). Therefore, they play an important role in customer satisfaction (Jauhari, Singh, \& Kumar, 2017). In this regard, customers can only be loyal to organizations if they are completely satisfied with the services that are offered and promised to them. Such level of adequate service can only be possible through a team of satisfied workers who are committed to the organization (Sarfraz \& Mahmood, 2017). FLEs need to interact effectively with their customers (Van Scheers \& Botha, 2014) and this interaction is contingent on their level of job satisfaction and motivation towards their work (Sony \& Mekoth, 2016). A satisfactory customer-employee relationship does not only retain customers, but also maintains a positive relationship between a customer and the organization as a whole (Premkumar \& Rajan, 2017).

Job satisfaction (dissatisfaction) refers to the balance of positive (negative) feelings that a worker has towards his/her work (Aziri \& Brikend, 2011), which further develops a positive relationship between motivation and job satisfaction (Van Scheers \& Botha, 2014). Motivation is the driving force that an organization uses to encourage employees towards its success (Akhtar, Hussain, Ali, \& Salman, 2014). Consequently, keeping employees motivated is extremely important for any organization. Motivation caters to two perspectives: (i) general commitment towards an endeavor; and (ii) specific needs of a person. The former refers to 'general work satisfaction or commitment', while the latter means 'specific satisfied 
needs' one acquires through his job in an organization (Pareek, 1974). Intrinsic motivation (motivators) refers to an inherent interest towards a job, whereas the extrinsic motivation (hygiene) refers to doing a job for its outcome (Cinar, Bektas, \& Aslan, 2011).

Even though Pakistan's telecommunication sector showed outstanding pace of growth, it has been identified that there is a gap in studying what motivates this sector's employees to increase their level of job satisfaction (Razzaq, et. Al, 2017). In order to take this discussion forward, the relevance of the double factor theory of motivation is examined in the context of the banking sector of Pakistan (Fareed \& Jan, 2016). For instance, Naseem (2018) tested the effects of job stress, happiness and life satisfaction on job satisfaction among employees of the telecommunication sector of Pakistan. Similarly, researchers have also analyzed the relationship of the incentive system and employee performance in telecom sector of Pakistan (Khan, Abbas, \& Zaki, 2017). Furthermore, the other studies have discussed the link between nonstandard working hour and employee turnover (Muhammad, 2017) to assess the impact of motivation. Herzberg's theory is one of the most commonly tested and applied theories in the current milieu.

In 1957, Herzberg explained the link between motivation and job satisfaction for the profession of engineers. Later, he bifurcated motivation into two constructs in order to measure the level of job satisfaction of employees in different firms (Herzberg, Mausner, \& Snyderman, 1959). Various studies have both supported as well as criticized Herzberg's approach to measure motivation by a different set of factors for the motivators and hygiene constructs. However, countless areas are untapped due to modernization, continuously changing business practices, gender diversity and evolving business and organizational cultures. This has led to changes in the motivating factors in many organizations, and has shifted the focus on studying different motivational theories as well. In this backdrop, this study focuses on studying Herzberg's motivation theory, and its prime purpose is to determine the relevance of underlying factors that can directly impact the job satisfaction of the FLEs in the telecommunication sector of Pakistan. His theory has been criticized for showing varying results depending on the nature of the task and specifications of the country of the sample. Few researchers also challenged the importance of dividing motivation into hygiene and 
motivators. Therefore, the study first dissects these two factors to identify the most relevant factors by going beyond of the two-factor categorization.

\section{Research Rationale}

There is no denying of the fact that the theory of Herzberg of employee motivation is very pertinent in explaining the work behaviors organizational employees. Nevertheless, this theory attracts substantial criticism from its critics (Deci \& Ryan, 2001; Steers, Mowday \& Shapiro, 2004). It is strongly contended that there is no need to revive the original theory as it lacks substantial influence in explaining employee motivation (Bassett-Jones \& Lloyd, 2005; Achie \& Kurah, 2016). In the similar vein, Onen and Maicibi (2004) have differed with Maidani (1991). They argued that one of the hygiene factor was originally a motivator in the study and this misclassification was caused due to the differences in the sample and organizational culture of employees. Smerek and Peterson (2007) found that only work itself (one factor) showed a significant impact on job satisfaction which highlights the need of studying these underlying factors as separate constructs to better understand what actually motivates the employees.

With respect to the reliability of the constructs, Manisera et al (2005) showed insignificant difference between the second order constructs of hygiene and motivation. Likewise, Yusoff et. al (2013) proposed to combine both of these factors into one factor after comparing the inconsistencies in the findings of the two-factor theory from various countries and industries. For instance, the tasks assigned to employees and the geographical regions play a crucial role in studying the relationship between motivation and job satisfaction (Islam and Saha, 2016). In the wake of this critique, this study aims to move beyond the dichotomy of two factor theory and examines the actual tenants of this theory for a better understanding of employee job satisfaction. Nonetheless, Herzberg's two-factor theory has pushed ahead in relevance and continues to be one of the most important theories of motivation being studied as a determinant of job satisfaction.

\section{Literature Review}

In 1959, Herzberg et al. suggested the two-dimensional paradigm of factors that affect motivation in employees, and from here on they developed the two-factor theory (Herzberg, 1966). This theory was 
elaborated by stating that a job's content, nature, and the tasks it entails were crucial to motivate employees to do their respective jobs (RuizPalomino, Saez-Martínez, \& Martínez-Canas, 2013). A dynamic approach, as postulated by an idealistic philosophical lens, argues that a man has two needs, one to avoid pain and another to grow psychologically (Rao, 1972). Despite the perennial claims that Herzberg's theory is being exhausted due to over application, recent research in the field of positive psychology has been found to show consistency with the core ideas of Herzberg's twofactor theory of motivation (Sachau, 2007). Indeed, Herzberg's work speaks volumes, but it is not put forth without its critics evaluating the possible weaknesses of the theory.

The significance of motivation is crucial in all firms to enhance employee performance, which is the key to an organization's growth. Therefore, multiple motivation practices have been adopted to meet the requirement of the workforce and its work environment (Ogbogu, 2017). Among the various theories, Herzberg's theory of motivation is the most popular theory in studying job satisfaction (Dion, 2006). Moreover, Herzberg's theory is applicable even after fifty years of examining employee behavior (Hoseyni et al., 2014), and is famously known as the, "motivation-hygiene theory". According to the tenants of this theory, motivating factors increase job satisfaction and hygiene factors decrease job dissatisfaction (Band, Shah, \& Sriram, 2016).

The traditional Herzberg approach represented both job satisfaction and dissatisfaction on the same continuum, but at opposite ends. Later on, satisfaction and dissatisfaction were separated into different sets of categories, each accompanied by distinct set factors. Hygiene factors decreased dissatisfaction, whereas it was the motivators that increased satisfaction. Hence, the updated two-factor theory that claimed satisfaction and dissatisfaction to be determined by different set of factors was reinforced (Brenner, Carmack, \& Weinstein, 1971). It must be noted that Herzberg's theory of motivation derived inspiration from Maslow's hierarchy of needs (Dartey-Baah \& Amoako, 2011). Hygiene factors, fulfilled "the need to avoid unpleasantness" while the motivation factors met "the need of the individual for self-growth and selfactualization” (Alshmemri, Maude, \& Phillip, 2017). 


\subsection{Hygiene and Motivators}

The presence of hygiene factor does not cause satisfaction on its own but nonetheless, its absence would cause dissatisfaction. Conducive "working conditions" is one of the main characteristics in the workplace that helps to avoid dissatisfaction in firms. Herzberg et al. (1959) proposed that hygiene factors were important in creating job satisfaction and Maidani (1991) corroborated that if these extrinsic variables are mishandled by an organization, it can create dissatisfaction among the employees.

The factors such as nature of work, recognition, advancement, growth and sense of achievement that one derives from work, and future opportunities impact the motivation of employees. For example, work itself includes a variety of characteristics of the job in hand, from how one participates in the work activities, to the control one has over assigned tasks. This leads to the sense of achievement one derives from the assigned task by the level of importance an employee assigns to it. If the firms provide all of these intrinsic factors to its employees, it will motivate employees towards their job (Raziq \& Maulabakhsh, 2015).

Few studies have historically refuted the findings of Herzberg et al. (1959) due to differences in the demographics of the samples of the types of industries, and their organisational cultures. Win (2006) tested the relevance of Herzberg theory in the nursing sector of Mayamar and Taiwan, showing a direct relationship between the intrinsic factors and job satisfaction for both countries. However, the extrinsic factors were found to be significant determinants only in Taiwan. Later on, Park and Rainey (2007) proposed that sometimes the extrinsic factors also tend to act as the intrinsic factors, which might positively impact job satisfaction as well. Tan \& Waheed (2011) have given precedence to the hygeine factors over the motivators. Herzberg's methodology has been criticized, thus bringing in some skepticism about the approach as well ( Ondrack, 1974).

\subsection{Job Satisfaction}

Job satisfaction is of great importance in the area of management, which has been studied prior to Herzberg's theory (Behling, Labovitz, \& Kosmo, 1968). It is affected by motivators and hygiene factors among the employees of both the public and private sector organizations (Hur, 2017). 
Whilst Herzberg's model stands first among the motivational theories, some studies extend their models further by bringing employee's emotional wellbeing into the equation (Noble, 2008). For understanding purposes, it is noted that job satisfaction refers to the degree to which people like their jobs (Muhammad, 2017).

A study on a high school teacher's group in Turkey suggested that both hygiene factors and motivation factors contribute to changes in job satisfaction (Atalic \& Canturk, 2016). The theory was validated even in a different cultural setting like Taiwan (Chu \& Kuo, 2015). Job dissatisfaction leads salespersons from both genders to leave their jobs, but their causes may vary (McNeilly \& Goldsmith, 1991). Similarly, the satisfaction of a salesperson is a function of their supervisor's consideration, participation, feedback and interaction (Teas \& Horrell, 2015). Even though, "age, sex, education, occupation and income" were all important variables in the earlier studies, but it became evident in the studies conducted later on that there are other variables that explained the effect of motivation on job more effectively (Izvercian, Potra, \& Ivascu, 2016).

In developed nations, and in research-based developing nations, females reported a difference in job satisfaction levels. In the United States, women reported higher levels of satisfaction than their male counterparts (Wharton, 1993). A study based on Filipino workers revealed that there is a definitive gender disparity, as the male managers reported that they were trusted with more responsibilities than their female colleagues (Hechanova, Alampay, \& Franco, 2006). The assignment of varying responsibilities is one of the core motivational factors which contribute to an increase in job satisfaction. It becomes evident that female workers are the victims of gender discriminations, thus in certain parts of the world they would report lower levels of satisfaction. A study conducted on the university graduates from Wisconsin showed that the female graduate population was quite dissatisfied due to the income disparity among genders (Hodson, 1983).

Despite the critiques, recent studies have highlighted that the stated factors emphasized by Herzberg's theory were essential in understanding job satisfaction. A study conducted on Ghanaian workers within the service industry found that multiple factors were of great importance to the workers themselves. Job security, their working conditions, 
relationship with subordinates and supervisors were all prerequisites for understanding whether or not they felt satisfied with their jobs (Sarwar \& Abugre, 2013). Although Herzberg's hygiene factors do play a role in the worker's satisfaction, employees would be more satisfied had they received more recognition for the work they did (Sarwar \& Abugre, 2013).

Despite the importance given to hygiene factors, it is concluded that motivational factors increase job satisfaction, and their absence leads to dissatisfaction among employees. But nonetheless, the hygiene factors should not be ignored (Pestonjee \& Basu, 1972). Furthermore, much of Herzberg's factors have been emphasized as determinants of job satisfaction thus providing further support for the two-factor theory of motivation (Joshi \& Sharma, 1997). Studies have also revealed that much of the listed satisfiers and motivators were in line with the two-factor theory.

A study done on Malaysian retail workers found that salespeople put a higher emphasis on hygiene factors (working conditions, money and company policy). When surveyed, however, motivational factors recognition in particular still proved important (Tan \& Waheed, 2011). Several studies show that workers of the service industry have indicated a great importance for hygiene factors in studying job satisfaction. However, this does not mean that motivational factors are to be ignored. The combination of both intrinsic and extrinsic factors should be studied as it broadens the scope of understanding (Yusoff, Kian, \& Idris, 2013) of job satisfaction.

Service employees are the backbone of the product that service industries provide (Hechanova, Alampay, \& Franco, 2006), thus the need to invest time in employee programmes would increase job satisfaction. To improve the job satisfaction of service workers, employers mostly focus on motivational factors. A study done on 954 Filipino service workers found that there was a positive relationship between job empowerment and job satisfaction (Hechanova, Alampay, \& Franco, 2006). Much of the lower paid service workers were far more inclined to be satisfied with their jobs if their immediate concerns were being catered to. Whereas the managerial staff tended to have more focus on the long-term prospects (Brown \& McIntosh , 2003). Similarly, in the service sector, employee satisfaction relies on making jobs more meaningful. Generally, service sector jobs that directly deal with the public are seen as emotionally exhausting (Wharton, 1993). 


\subsection{Hypotheses}

As per the foregoing review of the literature the following subsections presents the hypotheses of this study.

\subsubsection{Working Conditions}

Herzberg (1966) defined working conditions as the whole surrounding at work, which comprises of an employee's comfort in terms of physical and psychological aspects. It also consists of all the tools and machineries provided at work to ease the job that would fully protect an employee at a workplace. Working conditions have a positive relationship with job satisfaction, as a conducive environment keeps an employee motivated (Hayes, Bonner \& Douglas, 2015). Furthermore, working conditions also consist of the physical environment, which can include infrastructure and amenities; the mental environment, such as attitude and behavior of colleagues; and the social environment (Jain \& Kaur, 2014). Therefore, a Ribeiro, Assunção and de Araújo (2014) study showed that the highly satisfied physicians were the ones who had the support of their team, whereas, physicians working under stressful conditions were not satisfied with their jobs. Employees' working conditions consist of the terms and conditions of their employment (Al-Hamdan, Manojlovich, \& Tanima, 2017). Therefore, a healthy and comfortable work environment will motivate them and create job satisfaction (Robbins. 2001). Providing employees with a better working environment such as proper lighting, cleanliness and temperature allows them to work more efficiently and comfortably, therefore, increasing employee satisfaction (Aydogdu \& Asikgil, 2011; Raziq \& Maulabakhsh, 2015). Based on the above discussion, the following hypothesis is presented to examine the direct link between working condition and job satisfaction.

Hypothesis 1: Working Condition has a direct and positive relationship with job satisfaction.

\subsubsection{Company Policy}

According to Herzberg (1966) 'company policy' is defined as the systems and functions used for accomplishing tasks as per organizational set standards. According to Ahmed et al. (2010), research shows that 
employees feel more motivated when they are aware of organizational policies. In a similar study that was conducted about the faculty of various universities by Islam and Ali (2013), teachers were satisfied with their jobs because all the policies applicable on every faculty member were the same, and all the teachers were aware of it. Another study by Winer and Schiff (1980), and Lucas and Gresham (1985) stated in their findings that company policy was very crucial in motivating an employee, and ultimately achieving job satisfaction. Company policies that take care of their employees have shown reciprocity in terms of higher motivation and job satisfaction for more than sixty years (Gouldner, 1960). Therefore, human resources have to consider employee motivation when creating company policies to positively influence an employee's job satisfaction (Memon, Panhwar, \& Rohra, 2010). Chiang and Birtch (2011) stated that company policies that considered its employees' working environment, provided organizational support, and offered non-financial rewards, effectively increased the job satisfaction of its work force. Wong and Heng (2009) found that the implementation of company policy and procedures is essential for maintaining employee job satisfaction. Based on the above discussion, the following hypothesis is presented to examine the link between company policy and job satisfaction.

Hypothesis 2: Company policy has a positive and direct relationship with job satisfaction.

\subsubsection{Relationship with Supervisors}

Herzberg (1966) defines the relationship with supervisors as the relationship the employee has with his/her boss, supervisor, or manager. However, Griffin et al. (2001) stated that the support of the supervisor may not be of the utmost importance in some organizations, but it does have a positive relationship with job satisfaction. Employees often seek better career opportunities if their relationship with their supervisors is good. They are more likely to approach their supervisors for any work advice once an in-depth communication between the supervisor and the subordinate has been established (Chen \& Tjosvold, 2006). This cordial relationship motivates the subordinates to produce better results, and execute the tasks as per the job requirements, in return increasing the job satisfaction of the employees (Cheung, Wu, Chan, \& Wong, 2009). Other than this, mentorship between subordinate and a supervisor also 
positively affects job satisfaction. A healthy and motivating relationship of employees working in the public sector showed a positive impact on job satisfaction, when the supervisors were given autonomy in building healthy relationships with the junior employees (Kuvaas, 2009). Social relationships at a work place are essential for an employee's satisfaction, especially when the relation is with the supervisor (Jiang, Lin, \& Lin, 2011). However, "unethical treatment of employees" by managers at any level can lead to job dissatisfaction among employees, especially in the service sector organizations such as hotels (Wong \& Li, 2015). Based on the above discussion, the following hypothesis is presented to investigate the direct link between relationship with supervisor and job satisfaction.

Hypothesis 3: Relationship with supervisors has a positive and direct relationship with job satisfaction.

\subsubsection{Relationship with Peers}

Herzberg (1966) defines 'relationship with peers' as the relationship with colleagues at work for both genders. Khojasteh (1993) studied Herzberg's motivation theory applied on the managers of private and public sector organizations. She concluded that having a good interpersonal relationship with colleagues motivated the public sector managers more than the private sector managers. This was primarily because there was a difference in maintaining relationships with the colleagues in both the sectors. In a study conducted by Volkwein and Parmley (2000) on the administrative staff of higher education commission, found a positive impact on the job satisfaction level of the employees due to cordial teamwork among the peers at work. Similarly, receiving co-workers' appreciation was directly related to job satisfaction of the FLEs of different hotels (Alam, 2015). Understanding the relationship amongst the Japanese physicians also showed a positively significant impact on the job satisfaction levels of their colleagues (Wada et al., 2009). Another study by Islam and Ali (2013) applied Herzberg's motivation-hygiene theory on the teachers in the private universities of Peshawar, and found that the relations among the co-workers was highly significant in achieving job satisfaction. This is only possible with teamwork and an effective support system. Based on the above discussion, the following hypothesis is presented to ascertain the link between relationship with peers and job satisfaction. 
Hypothesis 4: Relationship with peers has a positive and direct relationship with job satisfaction.

\subsubsection{Money}

Herzberg (1966) defined 'money' as the amount of payment and remuneration employees receive for their work. According to a study by Johnson (1986), providing justifiable rewards to the employees keeps them motivated, and in return, their job satisfaction increases. Eccles (1991) supported this notion as he found that employees were consistent in the service behavior set by the organization when they were aware of the potential rewards they would possibly get in return. Robbins (2001) termed money as a scorecard, which employees use to assess their significance at a company, in comparison with other companies. When an employee knows that the salary they are receiving is sufficient, and better than what is being offered by other companies, he/she may exhibit commitment to that organization and as a result, their job satisfaction increases. Kovach (1987) stated that remuneration or salary is considered to be amongst the most important hygiene factor for younger, perhaps less experienced employees as their earnings are the lowest. Hence, a good pay is highly demanded by the employee (Linz \& Semykina, 2012). Moreover, Tang (2007) stated in the ideology of 'love for money', that employees are driven by high salaries, and are motivated once they are given a raise. This increases their job satisfaction.

In a survey by Yunus, Kevin and Dean (1990), employees assessed the different job characteristics and then ranked them in terms of those characteristics which hold the most importance to the employees. The findings showed that compensation was ranked as the highest motivator for job satisfaction, and an increase in salary was ranked as the highest motivator. Therefore, salary is the most important variable affecting job satisfaction (Wang \& Liesveld, 2015). Initially, Herzberg (1957) did not consider salary as an important determinant of motivation. However, he thoroughly studied the importance of salary on job satisfaction later (Herzberg, 1966). Many studies also supported him and found a significant relationship between pay and job satisfaction (Islam, Zaki, \& Ismail, 2008; Stringer, Didham, \& Theivananthampillai, 2011). Herzberg's hygiene factor such as 'pay/salary' as an extrinsic factor, showed minor but significant impact on the job satisfaction level of employees (Sachau, 2007). However, 
among the various factors of motivation, salary and relationship with and between colleagues were considered the most important factors ensuring job satisfaction in employees (David, Gidwani, Birthare, \& Singh, 2015; Islam \& Saha, 2016). Based on the above discussion, the following hypothesis can be presented to investigate between salary and job satisfaction.

Hypothesis 5: Salary has a positive and direct relationship with job satisfaction.

\subsubsection{Work Security}

Herzberg (1966) defined 'work security' as a phenomenon which includes all the dimensions of a job that protect the employees physically, mentally and personally, while retaining their jobs over the long term. Employees who had the security of retention over longer period showed higher job satisfaction in the private sector (Khojasteh, 1993). Moreover, aged employees were seen to be more motivated and satisfied with their jobs when offered job security as compared to higher monetary gains (Kovach, 1987). Moreover, Sledge, Miles and Coppage (2008) concluded in their study, based on the hotel industry, that the uncertainty of losing one's job was a factor that was hampering employee motivation; therefore, work security has a positive relationship with job satisfaction. Hence, confidence regarding employment can increase job satisfaction in all employees when they have work security (Theodossiou \& Vasileiou, 2007). Job security in terms of pre-defined contractual renewals to safeguard the employees from the risk of being unemployed has implications on the satisfaction levels of employees throughout the hierarchy (Danish \& Usman, 2010; Saraswathi, 2011). Based on the above discussion, the following hypothesis is presented to determine the link between work security and job satisfaction.

Hypothesis 6: Work security has a direct and positive relationship with job satisfaction.

\subsubsection{Work Itself}

Herzberg (1966) defined the concept of 'work itself' as the tasks, activities and responsibilities required to execute a job. Ahmed et al. (2010) showed a positive impact of work itself on job satisfaction for the administrative employees of the University of Punjab. Islam and Ali (2013) 
placed the variable of work itself as the most important motivator for the teachers of private universities of Peshawar. Moreover, Norizan's (2012) study suggested that offering adequately challenging tasks of the assigned work, and providing employees with the opportunity to use and enhance their skills lead to a positive impact on employees' job satisfaction. Another study by Delaney and Royal (2017) showed a positive relationship between work itself and job satisfaction, especially when employees find their work to be interesting and challenging. Furthermore, a study by Sledge et al. (2008) showed that the hotel industry employees in Brazil were contented with their jobs when their tasks and responsibilities were of their interest. This finding shows that the feature of work itself is a factor that significantly influences the motivation level of employees (Smerek \& Peterson, 2007). Substantial support in this regard, in multiple studies towards the importance of work itself has emerged as a dominant determinant of job satisfaction (Hossain \& Hossain, 2012; Omolo, 2015; Tyilana, 2005). Based on the above discussion, the following hypothesis is presented,

Hypothesis 7: Work itself has a positive and direct relationship with job satisfaction.

\subsubsection{Recognition}

'Recognition' is defined by Herzberg (1966) as public recognition by others, perhaps in the form of awards or evidence of a job well done. Employees who received recognition for their work by their supervisors showed higher satisfaction in those employees (Shore \& Shore, 1995). Similar findings were found in a study by Buchanan (1974), stating that employees who were recognized for their contribution in the success of organizations were more motivated towards their work, ultimately leading to higher job satisfaction. Hinkin and Schriesheim (2004) also concluded that there happens to be a positive relationship between employee recognition and job satisfaction, which signifies that an organization recognizes that a particular employee is satisfied with the job, when he/she display an increase in productivity. Managers in private and public sectors showed increased levels of job satisfaction when the press for their work recognized and perhaps appreciated them (Khojasteh, 1993).

According to Lester's (2013) study, people possess a basic need of appreciation or recognition. Similarly, in another study by Desai (2015), employees who received recognition for their work were more likely to be 
satisfied with their job. This brings to the belief that there is a significant relation between recognition and job satisfaction because financial benefits without any recognition lessen an employee's level of motivation (Ali \& Ahmed, 2009; Shah et al. 2012). Frontline employees established that nonfinancial rewards such as recognition were considered as contributing factors toward job satisfaction, as employees expect more than just financial rewards (Bustamam, Teng, \& Abdullah, 2014). Based on the above discussion, the positive and direct link between recognition and job satisfaction is presented in the following hypothesis.

Hypothesis 8: Recognition has a positive and direct relationship with job satisfaction.

\subsubsection{Advancement}

Herzberg (1966) defined advancement as an employee's prospect to develop within an organization for continuous career advancements. Lester's (2013) study suggests that growth is defined in both personal and professional aspects. Another study by Fareed and Jan (2016) stated that advancement include better opportunities to undergo professional training, learning new skills and gaining new knowledge. Similarly, in a study conducted by Olsen et al. (1995), to measure job satisfaction in the higher education sector, a positive relationship was revealed between career advancements and job satisfaction. Promotional and growth opportunities, or career advancements play a critical role for the positive relationship between job satisfaction and advancement (Ellickson \& Logsdon, 2001). Ellickson and Logsdon (2002) also identified career path advancements in a workplace as an important determinant of job satisfaction (Ting, 1997). Based on the above discussion, the following hypothesis is presented to examine the direct link between advancement and job satisfaction.

Hypothesis 9: Advancement has a positive and direct relationship with job satisfaction.

\subsubsection{Achievement}

Herzberg (1966) defined 'achievement' as success in achieving goals and objectives, which can be individualistic or in groups. Lambrou, Kontodimopoulos and Niakas (2010) conducted a study on a particular 
team of medical staff that showed that achievement was the most important factor in motivating employees, ultimately leading towards job satisfaction. The objectives such as self-efficacy and successfully attaining organizational goals increased the level of job satisfaction among the health professionals. The feeling of achievement or accomplishment significantly affects the level of job satisfaction among employees (Knight \& Westbrook, 1999). In a study by Sledge et al. (2008) that was conducted in Brazil, when assessing the job satisfaction of hotel industry, results revealed that most of the employees expressed a positive desire to achieve more objectives and goals, this showed a direct relationship with job satisfaction. Based on the above discussion, a direct and positive link between achievement and job satisfaction is proposed in the following hypothesis.

Hypothesis 10: Achievement has a positive and direct relationship with job satisfaction.

\subsubsection{Growth}

Herzberg (1966) defines growth as an employee's preference for progress, and the initiatives he makes for substantial personal growth. Due to strict patterns of hierarchy in the public organizations, keeping employees motivated can be a great challenge. Organizations should be able to meet their employees' expectations of career growth in order to keep them satisfied with their jobs (Rainey, 1989). According to Ramlall (2004) the managers should provide growth opportunities to their employees, if they aim to improve their job satisfaction. This would be useful because according to his studies, employees value growth as the most important motivator than others. Another study based in Taiwan by Chen, Chang and Yeh (2004) revealed that career development programs have a positive influence on the job satisfaction of employees. Based on the above discussion, the following hypothesis is presented to examine the direct and positive link between growth and job satisfaction.

Hypothesis 11: Growth has a positive and direct relationship with job satisfaction.

\section{Data and Methodology}

For the purpose of this study, the stratified random sampling technique (Naderi, 2012) was applied to collect the responses from front line 
employees working at various locations of the telecommunication business centers in Pakistan. The respondents included business center managers, senior executives and junior executives for the purpose of measuring job satisfaction of these front line employees only. A questionnaire was developed using Google forms, which was then emailed to the front line employees working at the business centers. The Email was sent to the all business unit employees located in all the metropolitan and non-metropolitan areas of different cities of Pakistan for capturing a realistic representation of the study population. From 370 possible responses, 284 responses were evaluated for statistical analysis. Only those questionnaires were considered for the study that were completely filled in by the respondents.

\subsection{Instruments}

To examine the variables of this research, the study used 30 items for measuring the independent variables (Tan \& Waheed, 2011) and four items to measure job satisfaction of the front line employees (Klassen, Usher, \& Bong, 2010; Stephanou, Gkavras, \& Doulkeridou, 2013) as shown in Table 1. The employees then evaluated their level of motivation and job satisfaction on a 5point Likert scale ranging from $1=$ strongly disagree to $5=$ strongly agree.

Table 1: Constructs and Measures

\begin{tabular}{lcl}
\hline Variables & Items & Studies \\
\hline Job Satisfaction & 4 & Klassen, Usher, \& Bong, (2010) \\
& & Stephanou, Gkavras, \& Doulkeridou (2013) \\
Achievement & 3 & Tan \& Waheed (2011) \\
Advancement & 2 & Akter, Wali, Kamal, Mukul, \& Mahmuda, (2017) \\
Work itself & 3 & Dikmen, Y1ldırım, Yıldırım, \& Ozbash, (2017) \\
Recognition & 3 & \\
Growth & 3 & \\
Company Policy & 3 & \\
Relationship & 3 & \\
Work Security & 3 & \\
Relationship with supervisor & 3 & \\
Money & 2 & \\
Working conditions & 2 & \\
\hline
\end{tabular}

\subsection{Data Analysis}

The Structural equation modelling (SEM) is run using Amos 18 for the confirmatory factor analysis (CFA), and the path analysis (Lam, Zhang, 
\& Baumb, 2001). CFA, (i) tests items for their factor loadings (ii), constructs for their reliability and validity, and (iii) model fits. The benchmark of the model fit for the study reports chi-square divided by the degrees of freedom $(\mathrm{CMIN} / \mathrm{df})<0.5$, goodness of fit index $(\mathrm{GFI})>0.9$ comparative fit index $(\mathrm{CFI})>0.9$, incremental fit index $>0.9$ (IFI), normed fit index (NFI) $>$ 0.9 , non-normed fit index (TLI) $>0.9$ and root mean square error of approximation (RAMSEA) $<0.8$ (Hooper, Coughlan, \& Mullen, 2008).

Factor loadings below 0.5 do not accurately assess the construct, therefore, they are not included in the structural regression analysis as stated by Hair, Black, Babin, Anderson and Tatham (2006), and Wu, Yeh and Hsiao (2011). The Composite reliability (CR) of the constructs are considered reliable, affirming that the items with a cutoff of 0.7 and above are related to their own construct (Straub, Boudreau, \& Gefen, 2004). The construct validity is tested by (i) convergent validity: constructs with Average Variance Extracted (AVE) of 0.5 or above (Davis, Bagozzi, \& Warshaw, 1989) and (ii) the discriminant validity (DV): examines that the constructs are different from each other, only if the square root of AVE is higher than the correlations of the inter-constructs (Hair et. al, 2010).

\section{Measurement Model and Results}

Pearson's correlation and variance inflation factor (VIF) values are shown in Table 2a and Table $2 b$. The correlation coefficients of all the constructs are significant at a p-value of 0.01 . The VIF values of the constructs are below a value of 3.5, showing no concerns of multicollinearity in between the constructs of the study (Guajrati, 2009). 
Table 2a: Correlation Coefficients

\begin{tabular}{|c|c|c|c|c|c|c|c|c|c|c|c|c|}
\hline Variables & Ach & Adv & Wits & Rec & Gro & Pol & Peer & Sup & Mon & WCn & WSc & $\mathrm{J}$ \\
\hline $\begin{array}{l}\text { Achievement } \\
\text { (Ach) }\end{array}$ & 1 & & & & & & & & & & & \\
\hline $\begin{array}{l}\text { Advancement } \\
\text { (Adv) }\end{array}$ & $.595^{* *}$ & 1 & & & & & & & & & & \\
\hline $\begin{array}{l}\text { Work Itself } \\
\text { (WIts) }\end{array}$ & $.650^{* *}$ & $.627^{* *}$ & 1 & & & & & & & & & \\
\hline $\begin{array}{l}\text { Recognition } \\
\text { (Rec) }\end{array}$ & $.638^{* *}$ & $.565^{* *}$ & $.669^{* *}$ & 1 & & & & & & & & \\
\hline Growth (Gro) & $.696^{* *}$ & $.638^{* *}$ & $.745^{* *}$ & $.684^{* *}$ & 1 & & & & & & & \\
\hline $\begin{array}{l}\text { Company Policy } \\
\text { (Pol) }\end{array}$ & $.634^{* *}$ & $.594^{* *}$ & $.644^{* *}$ & $.638^{* *}$ & $.672^{* *}$ & 1 & & & & & & \\
\hline $\begin{array}{l}\text { Relationship } \\
\text { with Peers } \\
\text { (Peer) }\end{array}$ & $.461^{* *}$ & $.398^{* *}$ & $.425^{* *}$ & $.500^{* *}$ & $.488^{* *}$ & $.524^{* *}$ & 1 & & & & & \\
\hline $\begin{array}{l}\text { Relationship } \\
\text { with Supervisors } \\
\text { (Sup) }\end{array}$ & $.470^{* *}$ & $.446^{* *}$ & $.492^{* *}$ & $.696^{* *}$ & $.540^{* *}$ & $.547^{* *}$ & $.535^{* *}$ & 1 & & & & \\
\hline Money (Mon) & $.240^{* *}$ & $.309^{* *}$ & $.269^{* *}$ & $.264^{* * *}$ & $.306^{* *}$ & $.299^{* *}$ & $.263^{* *}$ & $.306^{* *}$ & 1 & & & \\
\hline $\begin{array}{l}\text { Working } \\
\text { Conditions } \\
\text { (WCn) }\end{array}$ & $.565^{* *}$ & $.464^{* *}$ & $.575^{* *}$ & $.557^{* *}$ & $.594^{* *}$ & $.647^{* *}$ & $.561^{* *}$ & $.593^{* *}$ & $.475^{* *}$ & 1 & & \\
\hline $\begin{array}{l}\text { Work Security } \\
\text { (WSc) }\end{array}$ & $.464^{* *}$ & $.404^{* *}$ & $.473^{* *}$ & $.496^{* *}$ & $.519^{* *}$ & $.574^{* *}$ & $.528^{* *}$ & $.498^{* *}$ & $.455^{* *}$ & $.595^{* *}$ & 1 & \\
\hline $\begin{array}{l}\text { Job Satisfaction } \\
\text { (J) }\end{array}$ & $.680^{* *}$ & $.558^{* *}$ & $.680^{* *}$ & $.709^{* *}$ & $.700^{* *}$ & $.728^{* *}$ & $.595^{* *}$ & $.667^{* *}$ & $.511^{* *}$ & $.767^{* *}$ & $.637^{* *}$ & 1 \\
\hline
\end{tabular}

**. Correlation is significant at the 0.01 level (2-tailed).

Table 2b: Variance Infation Factors (VIFs)

\begin{tabular}{lc}
\hline Variables & Collinearity Statistics \\
\cline { 2 - 2 } & VIF \\
\hline Achievement & 2.446 \\
Advancement & 2.064 \\
Work Itself & 2.847 \\
Growth & 3.205 \\
Company Policy & 2.678 \\
Relationship with Peers & 1.770 \\
Relationship with & 2.334 \\
Supervisors & \\
Money & 1.433 \\
Working Conditions & 2.620 \\
Work Security & 1.990 \\
Recognition & 3.065 \\
\hline
\end{tabular}

a. Dependent Variable: Job Satisfaction 


\subsection{Descriptive Statistics}

The data contains 284 observations as the final observations. Work itself, has a value of 4.25 on average, and has a standard deviation of 0.88 . Moreover, recognition has a mean value of 4.21 , with 1.00 points deviation from this central value. The relationship with peers has a mean value of 4.33 and shows a 0.73 standard deviation. The relationship with supervisors is another variable controlled for in this study with a mean value of 4.16 , which deviates from its mean by 0.96 points. Money has a mean of 3.62, and a standard deviation of 1.05 points. The dependent variable, job satisfaction is equal to 4.01 on average, and with a standard deviation of 0.80 . All these variables have the minimum value of 1 , and maximum value of 5 . The maximum variance is in money and work itself as they both have the greatest mean value. Out of 284 respondents, 84 percent were males, 16 percent were females. In the category of employment, 71 percent respondents were outsourced and 29 percent were permanent. As per the location of the FLEs, 57 percent respondents were from a metro type city, and 43 percent were from a non-metropolitan city. From the hierarchy of these employees 15 percent workers were Business Center Managers, 9 percent were Senior Executives and 76 percent were Executives.

\subsection{Structural Equational Modelling}

The CFA results excuded the factor of 'advancement', a motivator due to a very low loading of 0.34 . Factor loadings for all other variables range from 0.62 to 0.93 , except for one item which was the 'relationship with the peers' showing a 0.54 . Composite reliability $(\mathrm{CR})$ and convergent validity (CV) holds for all the constructs, as the CR ranges from 0.75 to 0.90 , and the AVE from 0.56 to 0.75 (see Table 3). The variable 'work security' is omitted from further analysis as its CR and AVE values, 0.60 and 0.43 , do not conform with the construct's reliability and validity. Table 3 below reports, the CR, AVE and DV of the constructs, and factor loadings of each item. 
Table 3: Results of Measurement Model

\begin{tabular}{|c|c|c|c|c|c|}
\hline Variables & Items & Loadings & AVE & $\begin{array}{l}\text { Composite } \\
\text { Reliability }\end{array}$ & $\begin{array}{l}\text { Discriminant } \\
\text { Validity }\end{array}$ \\
\hline \multirow[t]{4}{*}{ Job Satisfaction } & Js1 & 0.71 & 0.57 & 0.87 & 0.75 \\
\hline & Js2 & 0.74 & & & \\
\hline & Js3 & 0.74 & & & \\
\hline & Js4 & 0.77 & & & \\
\hline \multirow[t]{2}{*}{ Achievement } & Ach1 & 0.85 & 0.67 & 0.80 & 0.82 \\
\hline & Ach2 & 0.77 & & & \\
\hline \multirow[t]{3}{*}{ Growth } & Grw1 & 0.81 & 0.74 & 0.90 & 0.86 \\
\hline & Grw2 & 0.87 & & & \\
\hline & Grw3 & 0.89 & & & \\
\hline \multirow[t]{3}{*}{ Work itself } & Wrk1 & 0.84 & 0.63 & 0.83 & 0.79 \\
\hline & Wrk2 & 0.69 & & & \\
\hline & Wrk3 & 0.84 & & & \\
\hline \multirow[t]{3}{*}{ Company Policy } & Cop1 & 0.82 & 0.57 & 0.80 & 0.76 \\
\hline & Cop2 & 0.81 & & & \\
\hline & Cop3 & 0.62 & & & \\
\hline \multirow{3}{*}{$\begin{array}{l}\text { Relationship with } \\
\text { the peers }\end{array}$} & Pee1 & 0.94 & 0.74 & 0.85 & 0.86 \\
\hline & Pee2 & 0.78 & & & \\
\hline & Pee3 & 0.55 & & & \\
\hline \multirow[t]{2}{*}{ Work Conditions } & Con1 & 0.79 & 0.61 & 0.76 & 0.78 \\
\hline & Con2 & 0.77 & & & \\
\hline \multirow[t]{2}{*}{ Money } & Mon1 & 0.81 & 0.64 & 0.78 & 0.80 \\
\hline & Mon2 & 0.79 & & & \\
\hline \multirow[t]{3}{*}{ Recognition } & Rec1 & 0.74 & 0.69 & 0.87 & 0.83 \\
\hline & Rec2 & 0.86 & & & \\
\hline & Rec3 & 0.88 & & & \\
\hline \multirow{3}{*}{$\begin{array}{l}\text { Relationship with } \\
\text { the supervisor }\end{array}$} & Sup1 & 0.89 & 0.75 & 0.90 & 0.87 \\
\hline & Sup2 & 0.85 & & & \\
\hline & Sup3 & 0.87 & & & \\
\hline
\end{tabular}

The model fit indexes reported in Table 4 show that the data fits the model very well as CMIN/d.f., GFI, CFI, NFI, IFI and TFI fall within the range mentioned by Zarei, Zainalipour, Mohammadi and Zare (2013). In the Table 4 below, the value for RMSEA is 0.06 which exceeds the acceptable range in few researches but McDonald and Ho (2002) and Hooper et al. (2008) mentioned a fit between 0.05 and 0.08 as good model fit. 
Table 4: Goodness-of-Fit Statistics (CFA)

\begin{tabular}{cc}
\hline Index & Model Fit Value \\
\hline Standalone Indexes & 2.00 \\
CMIN/DF & 0.06 \\
RMSEA & \\
Goodness of Fit & 0.90 \\
GFI & \\
Incremental Indexes & 0.91 \\
NFI & 0.95 \\
IFI & 0.94 \\
TLI & 0.94 \\
CFI & \\
\hline
\end{tabular}

Only six variables were included for conducting the structural analysis. The squared correlations of (i) job satisfaction, (ii) recognition, (iii) work itself, (iv) relationship with the peers, (v) relationship with the supervisors, and (vi) money were reported to be less than the AVE of each variable which support the benchmark for discriminant validity. Table 5 shows the model fit of structural analysis.

Table 5: Goodness-of-Fit Statistics

\begin{tabular}{cc}
\hline Index & Model Fit Value \\
\hline Standalone Indexes & 2.03 \\
CMIN/DF & 0.06 \\
RMSEA & \\
Goodness of Fit & 0.91 \\
GFI & \\
Incremental Indexes & 0.92 \\
NFI & 0.95 \\
IFI & 0.94 \\
TLI & 0.95 \\
CFI &
\end{tabular}

All the above-mentioned five independent variables showed a significant positive relationship with job satisfaction, among which three $\left(\mathrm{H}_{3}\right.$ : relationship with supervisors, $\mathrm{H}_{4}$ : relationship with peers and $\mathrm{H}_{5}$ : money) were hygiene factors, and two ( $\mathrm{H}_{7}$ : work itself and $\mathrm{H}_{8}$ : recognition) were motivational factors. Table 6 shows the results of the structural analysis results where, money significantly impacts dependent variable. Hence, a one-unit increase causes a 0.16 units increase in job satisfaction. 
The coefficient for relationship with peers was 0.34 , which implies a positive relationship with job satisfaction. The relationship with the supervisor is seen to have a significant link with job satisfaction. A one-unit increase leads to a 0.08 increase in the satisfaction level, ceteris paribus. Since, the $p$-value for this regressor is less than the level of significance that I have chosen ( $p=0.05)$, I may reject the null hypothesis in favor of the alternate, that the relationship with the supervisor does have an effect on job satisfaction. A one-unit increase in work itself is associated with a 0.31 units increase in job satisfaction, ceteris paribus. Similarly, a unit increase in recognition at work would cause the attained satisfaction to increase by 0.14 units.

\section{Table 6: Results of Structural Model (Structural Coefficients)}

\begin{tabular}{lcc}
\hline Independent Variables & Estimate & Significance \\
\hline Work itself & 0.312 & $* * *$ \\
Recognition & 0.142 & $* * *$ \\
Money & 0.16 & $* * *$ \\
Relationship with Peers & 0.341 & $* * *$ \\
Relationship with Supervisors & 0.083 & 0.013 \\
\hline
\end{tabular}

\section{Discussion}

The telecommunication services in Pakistan originated back in 1947. However, major changes took place in 1962 when the telegraph and telephone (T\&T) services were split into specialized units by the formation of autonomous T \& T and postal departments (Hanif, Hafeez, \& Riaz, 2010). Now, the telecom industry is an amalgamation of all the companies that provide phone services, internet and entertainment services, to domestic and commercial users in Pakistan (Bhatti, 2009). To sustain long-term growth, firms are not only focusing on customer acquisition through marketing activities, but are now investing heavily in maintaining customer relationship departments in order to retain existing and attract new customers, especially in highly saturated businesses like telecommunication.

This study examines the impact of Herzberg's Theory (Herzberg et al., 1959) on job satisfaction, which validates a few variables of hygiene and motivation factors in studying job satisfaction. Each variable of the motivator and hygiene factors has been dissected to study its impact on the job satisfaction of FLE employees of telecommunication companies in Pakistan. The listed results of the structure analysis in Table 6 show a 
strong positive relationship with job satisfaction, except for the final listed variable, relationship with supervisors that has a significant but slightly low impact on job satisfaction of the FLEs. The work itself feature was estimated to have a positive relation in the sample with job satisfaction showing the employees are satisfied with their particular occupations. This is common among workers holding managerial positions and employees in the service sector. A study on restaurant managers in Hong Kong confirms similar findings ( Lam, Baum, \& Pine, 2001). Therefore, the job an employee is doing has a significant impact on the satisfaction $s($ he) derives from the work (Hofmans, Gieter, \& Pepermans, 2013).

The job satisfaction levels of FLEs directly change with the recognition s(he) acquires for the work. Al-Moaely (2006) proposed that the absence of the recognition creates dissatisfaction among employees. Some firms found that presence of this factor increased job satisfaction, and its lack decreased job satisfaction (Green, 2000). The employees who received an adequate level of recognition found their work to be more challenging and empowering, and as a result, showed an increased level of job satisfaction.

Williams (2004) considered the relationship of employees with their supervisor to be extremely important. The study found that "employees leave bosses, not jobs", because they prefer supervisors who show trust, understanding and fairness towards them (Mahmoud, 2008). Alternatively, there is a positive impact of relationship with the peers on employee satisfaction if employees are respected by the co-workers. Employees stated that "friendly co-workers" made them feel good about themselves, and thus saw it as an important factor in deriving job satisfaction (Linz \& Semykina, 2012). One study based on recognition and job satisfaction conducted in Pakistan found that the employees anticipate appreciation more from co-workers than from their immediate supervisory authority such as their boss (Danish \& Usman, 2010).

Hence, the relationship with the peers is an important determinant of motivation for job satisfaction that is derived more when the fellow coworkers admire their work. Recognition is not only defined in terms of non-financial rewards, but with a changing organizational culture, it can be interpreted as the presence of programs offered by the firms to narrow the structural gaps between the employees (Dugguh \& Dennis, 2014). 
Thus, there is a growing emphasis on building relationships with peers. Hence, employees are motivated and satisfied when there is a stronger and positive relationship with the peers, as compared to their relationship with supervisors in the telecommunication industry for FLEs.

Employees who attach more importance to money are satisfied with their job when they receive a salary increment. Initially, Herzberg (1957) did not include salary as a motivator, but later on researchers found that among the human capital related aspects, salary is the most important variable affecting job satisfaction (Wang \& Liesveld, 2015). Dyer and Theriault (1976) found that the factor of salary cannot be ignored while testing the determinants of job satisfaction, as money is what they get in return for their effort. Interestingly, the significant estimate of money lies in the middle of the four other significant determinants of job satisfaction as shown in Table 6. Money shows a stronger relationship with job satisfaction in comparison to recognition and building cordial relations with the supervisors. However, it is not as highly ranked in comparison to the other two determinants (work itself and relationship with peers) of motivation. Though, a good pay is desired (Linz \& Semykina, 2012); studies have also found that money can only satisfy a worker for a short period of time, but cannot change the employee satisfaction in the long term (Teck-Hong \& Waheed, 2011). Hence, Table 6 shows that money indeed has a link with the job satisfaction. Nonetheless, work itself and the relationship with peers have a stronger impact on the level of satisfaction for the FLEs of the telecommunication industry.

As per these three extrinsic hygiene factors for FLEs, job satisfaction is increased when they receive support from their supervisors at a sufficient level, when their co-workers are helpful and they are fairly compensated for their work. Managers of the frontline employees have reported that a healthier relationship with the co-worker derives a higher level of job satisfaction. Whilst the relationship with supervisors is given less importance than the relationship with peers, still it cannot be completely disregarded, as there is an internal connection between the two variables. Co-workers assist in creating a bond between employees and their organizations (Bufquin, DiPietro, Orlowski, \& Partlow, 2017).

Table 6 exhibits all the variables that had a significant effect on employee's job satisfaction of FLEs. A few other variables were found to 
have a positive relationship as per Herzberg et al. (1959) findings, but did not show any significant relationship with the job satisfaction of the FLEs of the telecommunication sector. The responses corroborated that job achievement, working environment, career growth and company policy have no relationship with the employee's job satisfaction.

Past studies have found a positive link between the working conditions and one's level of job satisfaction (Raziq \& Maulabakhsh, 2015). This study particularly focuses on the factors that affect the satisfaction of the FLEs operating in business centers that strictly follow the rules and policies for sustaining the working conditions. Therefore, the environment in which these FLEs work in the telecommunication sector meets the benchmarks of workplace across the nation.

Alternatively, telecommunication companies continue to have favorable policies for their front line employees that maintain their job satisfaction (Khushk, 2019). As employees are satisfied with the agenda set by the organization, therefore respondents do not perceive company policies or the work environment as significant determinants of job satisfaction. Furthermore, as the relationship with peers is of more importance, it seems that for the FLEs, a comfortable social setting is more important than the physical attributes (policies and working conditions).

The prospect of achievement and growth were the other two variables disregarded by the respondents. Though, promotions may be desired to decrease job dissatisfaction; there seems to be a negative association between prospects of a promotion and job satisfaction (Linz \& Semykina, 2012). The reasoning for this can be attributed to the limited variation the nature or type of work offers for the employees at the business centers. The front line managers do not have many prospects of career progression beyond whatever they have already achieved. All 284 respondents of the study, listed their current job designation as either Executives, Senior Executives or Business Centre Managers, and out of them 33 percent have been working in the industry for five years or more. They have already achieved the highest level of designation; no promotion can be expected as there is only one business manager in each center. Thus, the respondents see no value in focusing their satisfaction on job achievements or prospects of career growth. However, this is why they are more concerned with money and a possible raise as it is the only mode of 
improvement that seems feasible in the near future. Regardless of any industry or work type, the pay is an extrinsic part of the motivation theory that leads to an employee's satisfaction (Ruiz-Palomino, Saez-Martínez, \& Martínez-Canas, 2013).

\section{Conclusions and Implications}

The data collected in this study would benefit the employers of the firms operating in the service industry in understanding which determinants of relevant factors that contribute towards the higher levels of job satisfaction in evolving economies. More importantly, this study takes the debate beyond the dichotomy of hygiene and motivation factors and examines the relevance of those factors that can directly influence the job satisfaction of employees. This study makes it clear that the social aspect attached to the idea a workplace has a great deal of impact on how an employee is satisfied with his work, especially concerning their relationship with peers. The people that surround an employee at work have an enormous impact on the satisfaction they derive from their job. For instance, an accommodating workplace leads to higher levels of satisfaction. Thus, managers can particularly focus on making their workplaces more accommodating for a healthier and friendly environment.

Similarly, the findings prove that work itself, is of utmost importance for job satisfaction. Hence, managers should ensure that the work that their front line employees do is meaningful for them. This can be achieved by attributing more challenging and versatile responsibilities to the employee. Moreover, managers should consider employing different approaches for both genders to address issues related to job satisfaction.

Whilst, it may seem from the data that supervisors (managers) seem to have a very limited effect on the levels of job satisfaction of the employees, it is an indicator of how employers seem to underplay their role in the employees work life. They should not simply provide employees with salaries, but should develop a better relationship with their workers. It would act as a form of positive reinforcement and can lead to higher levels of job satisfaction. 


\section{Limitations and Future Research Directions}

The sample was collected only from telecommunication employees, and more specifically frontline employees (FLEs), which implies that the results cannot be generalized for the entire population of the telecom sector employees. This study has extracted its sample of respondents from the telecommunication sector of mobile phone services only. Therefore, the sample is unevenly distributed between both genders; the male to female ratio is $5: 1$.

Furthermore, most of the past studies are based on diverse data examining multiple foreign firms, but the current study is based exclusively on the telecommunication sector of Pakistan. Herzberg's motivational theory can be based on time lagged and longitudinal studies which is a limitation of this study. Lastly, there are enormous cultural differences between Pakistan and other countries, not only in the workplace, but also in the industries. Thus, causing more limitation in the crystalizing of the findings with foreign findings as certain characteristics maybe more or less significant in certain parts of the world only.

Among motivators, such as achievement and growth; and hygiene factors, such as company policies and working conditions, discriminant validity was a factor that was missing. This could be due to the items applied to measure these variables. Therefore, a different scale may resolve the construct validity issue.

Lastly, this research can be extended in terms of its theoretical frame-work by adding more mediating variables or other dependent variables, such as job performance, gender, organization commitment and/or employee turnover. 


\section{References}

Achie, S. T., \& Kurah, J. T. (2016). The role of financial incentives as a motivator in employee's productivity in Nigeria Electricity Distribution Companies. International Journal of Research in Business Studies and Management, 3(1),1-8.

Ahmed, I., Nawaz, M. M., Iqbal, N., Ali, I., Shaukat, Z., \& Usman, A. (2010). Effects of motivational factors on employees job satisfaction a case study of University of the Punjab, Pakistan. International Journal of Business and Management, 5(3), 70-80.

Akhtar, N. A., Hussain, Z., Ali, S., \& Salman, M. (2014). Factors affecting employees motivation in banking sector of Pakistan. Journal of Asian Business Strategy, 4(10), 125.

Akter, A., Wali, S. B., Kamal, M. R., Mukul, A. Z., \& Mahmuda, M. (2017). Factors affecting job satisfaction of working mothers of readymade garments sector in Bangladesh. Issues in Business Management and Economics, 5(2), 25-36.

Al-Hamdan, Z., Manojlovich, M., \& Tanima, B. (2017). Jordanian nursing work environments, intent to stay, and job satisfaction. Journal of Nursing Scholarship, 49(1), 103-110

Alam, S. M. (2015). Factors affecting job satisfaction, motivation and turnover rate of medical promotion officer (MPO) in pharmaceutical industry: a study based in Khulna city. Asian Business Review, 1(2), 126-131.

Ali, R., \& Ahmed, M. S. (2009). The impact of reward and recognition programs on employee's motivation and satisfaction: an empirical study. International Review of Business Research Papers, 5(4), 270-279.

Al-Moaely, A. (2006). Job satisfaction among science subject teachers in secondary schools in Saudi Arabia. Scientific Journal of King Faisal University, 7(1), 161-189.

Alshmemri, M., Maude, L. S.-A., \& Phillip. (2017). Herzberg's Two-Factor Theory. Life Science Journal, 14(5), 12-16. 
Atalic, H. C., \& Canturk, N. (2016). Herzberg's motivation-hygiene theory applied to high school teachers in Turkey. European Journal of Multidisciplinary Studies, 1(4), 90-97.

Aydogdu, S., \& Asikgil, B. (2011). An empirical study of the relationship among job satisfaction, organizational commitment and turnover intention. International Review of Management and Marketing, 1(3), 43-53.

Aziri, \& Brikend. (2011). Job Satisfaction: A literature review. Management Research and Practice, 3(4), 77-86.

Band, G., Shah, N. V., \& Sriram, R. (2016). Herzberg Two Factor Theory among the Management Faculty in Nagpur city. International Conference on Management and Information Systems, 23, 13-21.

Bassett-Jones, N., \& Lloyd, G. C. (2005). Does Herzberg's motivation theory have staying power? Journal of Management Development, 24(10), 929-943.

Behling, O., Labovitz, G., \& Kosmo, R. (1968). The Herzberg Controversy: A Critical Reappraisal. The Academy of Management Journal, 11(1), 99-108..

Bhatti, H. (2009). Telecom Industry of Pakistan-Present and Future trends. Retrieved from https://www.scribd.com/doc/54219071/TelecomIndustry-of-Pakistan

Brenner, V. C., Carmack, C. W., \& Weinstein, M. G. (1971). An Empirical Test of the Motivation-Hygiene Theory. Journal of Accounting Research (Autumn), 359-366.

Brown, D., \& McIntosh , S. (2003). Job satisfaction in the low wage service sector. Applied Economics, 35(10), 1241-1254.

Buchanan, B. (1974). Government managers, business executives, and organizational commitment. Public Administration Review, 34(4), 339-347.

Bufquin, D., DiPietro, R., Orlowski, M., \& Partlow, C. (2017). The influence of restaurant co-workers' perceived warmth and competence on 
employees' turnover intentions: The mediating role of job attitudes. International Journal of Hospitality Management, 60(Special Issue), 13-22.

Bustamam, F. L., Teng, S. S., \& Abdullah, F. Z. (2014). Reward management and job satisfaction among frontline employees in hotel industry in Malaysia. Procedia-Social and Behavioral Sciences, 144, 392-402.

Chen, T. Y., Chang, P. L., \& Yeh, C. W. (2004). An investigation of career development programs, job satisfaction, professional development and productivity: The case of Taiwan. Human Resource Development International, 7(4), 441-463.

Chen, Y. F., \& Tjosvold, D. (2006). Participative leadership by American and Chinese managers in China: The role of relationships. Journal of Management Studies, 43(8), 1727-1752.

Cheung, M. F., Wu, W. P., Chan, A. K., \& Wong, M. M. (2009). Supervisorsubordinate guanxi and employee work outcomes: The mediating role of job satisfaction. Journal of Business Ethics, 88(1), 77-89.

Chiang, F. F., \& Birtch, T. A. (2011). Reward climate and its impact on service quality orientation and employee attitudes. International Journal of Hospitality Management, 30 (1), 3-9.

Chu, H. C., \& Kuo, T. Y. (2015). Testing Herzberg's Two-Factor Theory. The Journal of Human Resource and Adult Learning, 11 (1), 54-65.

Cinar, O., Bektas, C., \& Aslan, I. (2011). A motivation study on the effectiveness of intrinsic and extrinsic factors. Economics $\mathcal{E}$ Management, 16(5), 690-695.

Danish, R. Q., \& Usman, A. (2010). Impact of reward and recognition on job satisfaction and motivation: An empirical study from Pakistan. International Journal of Business and Management, 5(2), 159-167.

Dartey-Baah, K., \& Amoako, G. K. (2011). Application of Frederick Herzberg's Two-Factor theory in assessing and understanding employee motivation at work:a Ghanaian Perspective. European Journal of Business and Management, 3(9), 1-8. 
David, S., Gidwani, R., Birthare, N., \& Singh, P. (2015). Impacts of job satisfaction and organizational commitment: A study describing influence of gender difference on job satisfaction and organizational commitment. International Journal of Core Engineering and Management, 2(1), 93-111.

Davis, F. D., Bagozzi, R. P., \& Warshaw, P. R. (1989). User Acceptance of Computer Technology: A Comparison of Two Theoretical Models. Management Science, 35(8), 289-1003.

Deci, E. L., Koestner, R., \& Ryan, R. M. (2001). Extrinsic rewards and intrinsic motivation in education: Reconsidered once again. Review of Educational Research, 71(1), 1-27.

Delaney, M. L., \& Royal, M. A. (2017). Breaking engagement apart: The role of intrinsic and extrinsic motivation in engagement strategies. Industrial and Organizational Psychology, 10(1), 127-140.

Desai, A., \& Kleiner, B. (2015). Excellence in Incentive Programs. Business Journal for Entrepreneurs, 2015(3), 13-23.

Dikmen, T., Yıldırım, D. D., Yıldırım, A., \& Ozbash, S. (2017). Examining Internal and External Motivational Factors in Job Satisfaction of Public Institution Managers and Employees, Khazar Journal of Humanities and Social Sciences. 20, 298-318.

Dion, M. J. (2006). The impact of workplace incivility and occupational stress on the job satisfaction and turnover intention of acute care nurses. Retrieved from ProQuest: https://search.proquest.com/openview/753cbb7cbf fb9b155e0c63eb7464a0a1/1?pq-origsite $=$ gscholar\&cbl=18750\&diss $=y$

Dugguh, S. I., \& Dennis, A. (2014). Job satisfaction theories: Traceability to employee performance in organizations. IOSR Journal of Business and Management, 16(5), 11-18.

Dyer, L., \& Theriault, R. (1976). The determinants of pay satisfaction. Journal of Applied Psychology, 61(5), 596.

Eccles, R. G. (1991). The performance measurement manifesto. Harvard Business Review, 69(1), 131-137. 
Ellickson, M. C., \& Logsdon, K. (2001). Determinants of job satisfaction of municipal government employees. State and Local Government Review, 33(3), 173-184.

Ellickson, M. C., \& Logsdon, K. (2002). Determinants of job satisfaction of municipal government employees. Public Personnel Management, 31(3), 343-358.

Elnaga, A., \& Imran, A. (2013). The effect of training on employee performance. European Journal of Business and Management, 5(4), 137147.

Fareed, K., \& Jan, F. A. (2016). Cross-Cultural Validation Test of Herzberg's Two Factor Theory: An Analysis of Bank Officers Working in Khyber Pakhtunkhwa. Journal of Managerial Sciences, 10(2)285-300.

Green, J. (2000). Job satisfaction of community college chairpersons (Doctoral dissertation, Virginia Polytechnic Institute and State University, 2000). Electronic Theses $\mathcal{E}$ Dissertations. Retrived from, https://vtechworks.lib.vt.edu

Griffin, M. A., Patterson, M. G., \& West, M. A. (2001). Job satisfaction and teamwork: The role of supervisor support. Journal of Organizational Behavior: The International Journal of Industrial, Occupational and Organizational Psychology and Behavior, 22(5), 537-550.

Gouldner, A. W. (1960). The norm of reciprocity: A preliminary statement. American Sociological Review, 25, 161-178.

Williams, G.J. (2004). The effects of 'high commitment'HRM practices on employee attitude: The views of public sector workers. Public Administration, 82(1), 63-81.

Gujarati, D.N.(2009). Basic Econometrics. Gautam Budh Nagar Noida, India. Tata McGraw-Hill Education.

Hair, J. F., Black, W. C., Babin, B. J., Anderson, R. E., \& Tatham, R. L. (2006). Multivariate data analysis ( $6^{\text {th }}$ ed.). Upper Saddle River, NJ: Pearson. 
Hair, J. F., Anderson, R. E., Tatham, R. L., \& William, C. Black.(2010). Multivariate Data Analysis.

Hanif, M., Hafeez, S., \& Riaz, A. (2010). Factors affecting customer satisfaction. International Research Journal of Finance and Economics, 60(1), 44-52.

Hayes, B., Bonner, A., \& Douglas, C. (2015). Haemodialysis work environment contributors to job satisfaction and stress: a sequential mixed methods study. BMC nursing, 14(1), 1-13.

Hechanova, R. M., Alampay, R. B., \& Franco, E. P. (2006). Psychological empowerment, job satisfaction and performance among Filipino service workers. Asian Journal of Social Psychology, 9(1), 72-78.

Herzberg, F., Mausner, B., \& Snyderman, B. B. (1959). The Motivation to Work (2nd ed.). NewYork, NY: John Wiley \& Sons.

Herzberg, F. (1966). Work and the nature of man. Cleveland. World, 290, 339-341.

Hinkin, T. R., \& Schriesheim, C. A. (2004). “If You Don't Hear from Me You Know You Are Doing Fine" The Effects of Management Nonresponse to Employee Performance. Cornell Hotel and Restaurant Administration Quarterly, 45(4), 362-372.

Hodson, R. (1983). Gender Differences in Job Satisfaction: Why Aren't Women More Dissatisfied? The Sociological Quarterly, 30(3), 385-399.

Hofmans, J., Gieter, S. D., \& Pepermans, R. (2013). Individual differences in the relationship between satisfaction with job rewards and job satisfaction. Journal of Vocational Behavior, 82(1), 1-9.

Hooper, D., Coughlan, J., \& Mullen, M. R. (2008). Structural equation modelling: Guidelines for determining model fit. Electronic Journal of Business Research Methods, 6(1), 53-60.Hoseyni, S. N., Mirzaei, M., Faryabi, R., Ardekan, M., Mohsen, A., Shaker Ardekani, M., \& Mirzaei Alavijeh, M. (2014). Effective Factors in Job Motivation of Faculty Members in Shahid Sadoughi University of Medical 
Sciences: an Application of Herzberg's Motivation Theory. Iranian Journal of Medical Education, 13(12), 1040-1050.

Hossain, M. K., \& Hossain, A. (2012). Factors affecting employee's motivation in the fast food industry: The case of KFC UK Ltd. Research Journal of Economics, business and ICT, 5, 21-30.

Hur, Y. (2017). Testing Herzberg's Two-Factor Theory of Motivation in the Public Sector: Is it Applicable to Public Managers? Public Organization Review, 18(3), 329-343.

Islam, N., \& Saha, G. C. (2016). Job satisfaction of bank officers in Bangladesh. Retrieved from https://papers.ssrn.com/sol3/papers.cfm?abstract_id=2856224

Islam, R., Zaki, H., \& Ismail, A. (2008). Employee motivation: a Malaysian perspective. International Journal of Commerce and Management, 18 $(4), 44-362$

Islam, N., \& Saha, G. (2016). Job satisfaction of bank officers in Bangladesh. Retrieved from, doi:10.2139/ssrn.2856224

Islam-Ul, S., \& Ali, N. (2013). Motivation-Hygiene Theory: Applicability on Teachers. Journal of Managerial Sciences, 7(1), 87-104.

Izvercian, M., Potra, S., \& Ivascu, L. (2016). Job Satisfaction Variables: A Grounded Theory Approach. Social and Behavioral Sciences, 221(2016), 86-94.

Jain, R., \& Kaur, S. (2014). Impact of work environment on job satisfaction. International Journal of Scientific and Research Publications, 4(1), 1-8.

Jauhari, H., Singh, S., \& Kumar, M. (2017). How does transformational leadership influence proactive customer service behavior of frontline service employees? Examining the mediating roles of psychological empowerment and affective commitment. Journal of Enterprise Information Management, 30 (1), 30-48. 
Jiang, D. Y., Lin, Y. C., \& Lin, L. C. (2011). Business moral values of supervisors and subordinates and their effect on employee effectiveness. Journal of Business Ethics, 100 (2), 239-252.

Johnson, S. M. (1986). Incentives for teachers: What motivates, what matters. Educational Administration Quarterly, 22(3), 54-79

Joshi, R. J., \& Sharma, B. R. (1997). Determinants of Managerial Job Satisfaction in a Private Organisation. Indian Journal of Industrial Relations, 33 (1), 48-67.

Khan, A. A., Abbas, N., \& Zaki, K. A. (2017). Effect of Incentives Based Two Factor Theory on Employee Performance in Telecom. The Nucleus, 54 (3), 173-180.

Khojasteh, M. (1993). Motivating the private vs. public sector managers. Public Personnel Management, 22(3), 391-401.

Khushk, A. A. (2019). Impact of HR Policies and Practices on EmployeeJob Satisfaction: Evidence from Pakistan Telecommunication Ltd (PTCL) Hyderabad, Pakistan. SEISENSE Journal of Management, 2(2), 48-57.

Klassen, R. M., Usher, E. L., \& Bong, M. (2010). Teachers' collective efficacy, job satisfaction, and job stress in cross-cultural context. The Journal of Experimental Education, 78(4), 464-486.

Knight, P. J., \& Westbrook, J. (1999). Comparing employees in traditional job structures vs telecommuting jobs using Herzberg's hygienes \& motivators. Engineering Management Journal, 11(1), 15-20.

Kovach, K. A. (1987). What motivates employees? Workers and supervisors give different answers. Business Horizons, 30(5), 58-65.

Kuvaas, B. (2009). A test of hypotheses derived from self-determination theory among public sector employees. Employee Relations, 31(1), 39-56. 
Lam, T., Baum, T., \& Pine, R. (2001). Study of managerial job satisfaction in Hong Kong's Chinese restaurants. International Journal of Contemporary Hospitality Management, 13(1), 35-42.

Lam, T., Zhang, H., \& Baumb, T. (2001). An investigation of employees' job satisfaction: The case of hotels in Hong Kong. Tourism Management, 22(2), 157-165.

Lambrou, P., Kontodimopoulos, N., \& Niakas, D. (2010). Motivation and job satisfaction among medical and nursing staff in a Cyprus public general hospital. Human Resources for Health, 8, 26-26.

Lester, D. (2013). Measuring Maslow's hierarchy of needs. Psychological Reports, 113(1), 15-17.

Linz, S. J., \& Semykina, A. (2012). What makes workers happy? Anticipated rewards and job satisfaction. Industrial Relations: A Journal of Economy and Society, 51(4), 811-844.

Lucas Jr, G. H., \& Gresham, L. G. (1985). Power, conflict, control, and the application of contingency theory in marketing channels. Journal of the Academy of Marketing Science, 13(3), 25-38.

Mahmoud, A. H. (2008). A study of nurses' job satisfaction: the relationship to organizational commitment, perceived organizational support, transactional leadership, transformational leadership, and level of education. European Journal of Scientific Research, 22 (2), 286-295.

Maidani, E. A. (1991). Comparative study of Herzberg's two-factor theory of job satisfaction among public and private sectors. Public Personnel Management, 20(4), 441-448.

Maria Stock, R. J. (2017). Frontline Employees' Innovative Service Behavior as Key to Customer Loyalty: Insights into FLEs' Resource Gain Spiral. Journal of Product Innovation Management, 34(2), 223-245.

Memon, S. B., Panhwar, A. I., \& Rohra, L. C. (2010). Investigating the mediating role of human resource policies in employee retention. Australian Journal of Basic and Applied Sciences, 4(8), 40464057. 
Manisera, M., Dusseldorp, E., \& Van Der Kooij, A. J. (2005). Component structure of job satisfaction based on Herzberg's theory. Rapporti di Ricerca del Dipartimento di Metodi Quantitativi, Brescia University, Working paper, 253, Retrieved from http://www.datatheory.nl/ pages/fullmanuscript_final_epm.pdf.pdf

McDonald, R. P., \& Ho, M. H. (2002). Principles and practice in reporting structural equation analyses. Psychological Methods, 7(1), 64-82.

McNeilly, K., \& Goldsmith, R. E. (1991). The moderating effects of gender and performance on job satisfaction and intentions to leave in the sales force. Journal of Business Research, 22(3), 219-232.

Muhammad, A. \&. (2017). The Impact of Non-Standard Hours on Turnover Intentions: Evidence from Telecom Sector. SSRN Electronic Journal. Retrived from, doi:10.2139/ssrn.2899421

Naderi, A. N. (2012). Teachers: emotional intelligence, job satisfaction, and organizational commitment. Journal of Workplace Learning, 24(4), 256-269.

Naseem, K. (2018). Job Stress, Happiness and Life Satisfaction: The Moderating Role of Emotional Intelligence Empirical Study in Telecommunication Sector Pakistan. Journal of Social Sciences and Humanity Studies, 4(1), 7-14.

Noble, C. H. (2008). The Influence of Job Security on Field Sales Manager Satisfaction: Exploring Frontline. The Journal of Personal Selling and Sales Management, Vol. 28 (3), pp. 247-261.

Norizan, I. (2012). Organizational commitment and job satisfaction among staff of higher learning education institutions in Kelantan (Doctoral dissertation, University Utara Malaysia), Retrieved from http://etd.uum.edu.my/3003/3/Norizan_Ismail.pdf

Ogbogu, C. O. (2017). The Effects of Motivation on Staff Job Performance: Evidences from the Lagos State Ministry of Environment, Nigeria. Journal of Sustainable Development, 10 (2), 183. 
Olsen, D., Maple, S. A., \& Stage, F. K. (1995). Women and minority faculty job satisfaction: Professional role interests, professional satisfactions, and institutional fit. The Journal of Higher Education, 66(3), 267-293.

Omolo, P. A. (2015). Effect of motivation on employee performance of commercial banks in Kenya: A case study of Kenya Commercial Bank in Migori County. International journal of human resource studies, 5(2), 87-103.

Ondrack, D. (1974). Defense Mechanisms and the Herzberg Theory: An Alternate Test. The Academy of Management Journal, 17(1), 78-79.

Onen, D., \& Maicibi, A. N. (2004). The applicability of Herzberg's twofactor theory on the junior non-academic staff of Makerere University. Makerere Journal of Higher Education, 1(1), 143-152.

Pareek, U. (1974). A Conceptual Model of Work Motivation. Indian Journal of Industrial Relations,10(1), 15-31.

Park, S. M., \& Rainey, H. G. (2007). Antecedents, mediators, and consequences of affective, normative, and continuance commitment: Empirical tests of commitment effects in federal agencies. Review of Public Personnel Administration, 27(3), 197-226.

Pestonjee, D., \& Basu, G. (1972). A Study of Job Motivations of Indian Executives. Indian Journal of Industrial Relations, 8(1), 3-16.

Premkumar, G., \& Rajan, J. (2017). Customer Retention in Mobile Telecom Service Market in India: Opportunities and Challenges. UshusJournal of Business Management, 12(2), 17-29.

Rainey, H. G. (1989). Public management: Recent research on the political context and managerial roles, structures, and behaviors. Journal of Management, 15(2), 229-250. .

Ramlall, S. (2004). A review of employee motivation theories and their implications for employee retention within organizations. Journal of American academy of business, 5(1/2), 52-63. 
Rao, G. S. (1972). Theoretical and Empirical Considerations of the TwoFactor Theory of Job Satisfaction. Indian Journal of Industrial Relations, 7(3), 311-330.

Raziq, A., \& Maulabakhsh, R. (2015). Impact of Working Environment on Job Satisfaction. Procedia Economics and Finance, 23, 712-725.

Razzaq, S., Aslam, U., Bagh, T., \& Saddique, S. (2017). The impact of human resource management practices on employee commitment: Evidences from Pakistan Telecom Sector. International Journal of Academic Research in Business and Social Sciences, 7(7), 649-667.

Ribeiro, R. B. N., Assunção, A. Á., \& de Araújo, T. M. (2014). Factors associated with job satisfaction among public-sector physicians in Belo Horizonte, Brazil. International Journal of Health Services, 44(4), 787-804.

Robbins, S. P. (2001). Organizational behavior: global and Southern African perspectives. Cape Town, South Africa, Pearson .

Ruiz-Palomino, P., Saez-Martínez, F. J., \& Martínez-Canas, R. (2013, November). Understanding Pay Satisfaction: Effects of Supervisor Ethical Leadership on JobMotivating Potential Influence. Journal of Business Ethics, 118(1), 31-43.

Sachau, D. A. (2007). Resurrecting the Motivation Hygiene Theory: Herzberg and the Positive Psychology Movement. Human Resource Development Review, 6 (4), 377-393.

Santos-Vijande, M. L., López-Sánchez, Á. J., \& Rudd, J. (2016). Frontline employees' collaboration in industrial service innovation: routes of co-creation's effects on new service performance. Journal of the Academy of Marketing Science, 44(3), 350-375.

Saraswathi, D. (2011). A study on factors that motivate IT and non-IT sector employees: A comparison. Chief patron chief patron. International Journal of Research in Computer Application and Managment, 1(2), 72-77.

Sarfraz, R., \& Mahmood, B. (2017). Loyalty Breeds Loyalty: Nailing Customer Churn Through Satisfied and Loyal Employees in 
Telecom Sector of Pakistan. International Journal of Management Sciences and Business Research, 6(3),52-56.

Sarwar, S., \& Abugre, J. (2013). The influence of rewards and job satisfaction on employees in the service industry. The Business $\mathcal{E}$ Management Review, 3(2), 22-32.

Shah, M. J., Akhtar, G., Zafar, H., \& Riaz, A. (2012). Job satisfaction and motivation of teachers of public educational institutions. International Journal of Business and Social Science, 3(8), 271-281.

Shore, L. M., \& Shore, T. H. (1995). Organizational politics, justice, and support: Managing the social climate of the workplace. Perceived organizational support and organizational justice, 1, 149-164.

Sledge, S., Miles, A. K., \& Coppage, S. (2008). What role does culture play? A look at motivation and job satisfaction among hotel workers in Brazil. The International Journal of Human Resource Management, 19(9), 1667-1682.

Smerek, R. E., \& Peterson, M. (2007). Examining Herzberg's theory: Improving job satisfaction among non-academic employees at a university. Research in Higher Education, 48(2), 229-250.

Sony, M., \& Mekoth, N. (2016). The relationship between emotional intelligence, frontline employee adaptability, job satisfaction and job performance. Journal of Retailing and Consumer Services, 30, 20-32.

Steers, R. M., Mowday, R. T., \& Shapiro, D. L. (2004). Introduction to special topic forum: The future of work motivation theory. The Academy of Management Review, 29(2),379-387

Stephanou, G., Gkavras, G., \& Doulkeridou, M. (2013). The role of teachers' self- and collective-efficacy beliefs on their job satisfaction and experienced emotions in school. Psychology, 4(3A), 268-278. https://doi.org/10.4236/psych.2013.43A040Straub, D., Boudreau, M., \& Gefen, D. (2004). Validation guidelines for IS positivist research. The Communications of the Association for Information Systems, 13(1-70), 1-67. 
Stringer, C., Didham, J., \& Theivananthampillai, P. (2011). Motivation, pay satisfaction, and job satisfaction of front-line employees. Qualitative Research in Accounting \& Management, 8(2), 161-179.

Tan, T., \& Waheed, A. (2011). Herzberg's motivation-hygiene theory in the Malysian retail sector: the mediating effect of love of $\mathrm{m}$ oney. Asian Academy of Management Journal, 16(1), 73-94.

Tang, T. L. P. (2007). Income and quality of life: Does the love of money make a difference?. Journal of Business Ethics, 72(4), 375-393.

Taylor, J. (2014). Public service motivation, relational job design, and job satisfaction in local government. Public Administration, 92(4), 902918.

Teas, R. K., \& Horrell, J. F. (2015). An Empirical Analysis of the Relationship Between Sales Supervisory Behavior and Salesforce Job Satisfaction. In Marketing Horizons: A 1980's Perspective, Springer, Cham., 73-77. doi:10.1007/978-3-319-10966-4_17

Teck-Hong, T., \& Waheed, A. (2011). Herzberg's motivation-hygiene theory and job satisfaction in the Malaysian retail sector: The mediating effect of love of money. Asian Academy of Management Journal, 16(1), 73-94.

Theodossiou, I., \& Vasileiou, E. (2007). Making the risk of job loss a way of life: Does it affect job satisfaction?. Research in Economics, 61(2), 7183

Ting, Y. (1997). Determinants of job satisfaction of federal government employees. Personnel Administration, 26(3), 313-334.

Tyilana, X. E. (2005). The impact of motivation on job satisfaction amongst employees of a national broadcaster. Doctoral dissertation, University of Johannesburg. Retrieved from http://ujcontent.uj.ac.za

Van Scheers, L., \& Botha, J. (2014). Analysing relationship between employee job satisfaction and motivation. Journal of Business and Retail Management Research, 9(1), 98-109. 
Volkwein, J. F., \& Parmley, K. (2000). Comparing administrative satisfaction in public and private universities. Research in Higher Education, 41(1), 95-116.

Wada, K., Arimatsu, M., Higashi, T., Yoshikawa, T., Oda, S., Taniguchi, H., \& Aizawa, Y. (2009). Physician job satisfaction and working conditions in Japan. Journal of Occupational Health, 51(3), 261-266.

Wang, Y., \& Liesveld, J. (2015). Exploring job satisfaction of nursing Faculty: theoretical approaches. Journal of Professional Nursing, 31(6), 482-492.

Wharton, A. S. (1993). The Affective Consequences of Service Work: Managing Emotions on the Job. Work and Occupations, 20(2), 205232.

Win, H. H. (2006). The importance of intrinsic and extrinsic motivation factors as determinants of nurses' job satisfaction: Empirical study of Taiwan and Myanmar. Unpublished dissertation. National Cheng Kung University, Tainan, Taiwan.

Winer, L., \& Schiff, J. S. (1980). Industrial salespeople's views on motivation. Industrial Marketing Management, 9(4), 319-323.

Wong, S. C., \& Li, J. S. (2015). Will hotel employees' perception of unethical managerial behavior affect their job satisfaction? A study of Chinese hotel employees in China. International Journal of Contemporary Hospitality Management, 27(5), 853-877.

Wong, E. S. K., \& Heng, T. N. (2009). Case study of factors influencing job satisfaction in two Malaysian universities. International Business Research, 2(2), 86-98.

Wu, P. C., Yeh, G. Y.-Y., \& Hsiao, C.-R. (2011). The effect of store image and service quality on brand image and purchase intention for private label brands. Australasian Marketing Journal, 19(1), 30-39.

$\mathrm{Xu}, \mathrm{H}$. and Tracey, T.J. (2017), Use of multi-group confirmatory factor analysis in examining measurement invariance in counseling 
psychology research, The European Journal of Counselling Psychology, $6(1), 75-82$.

Yunus, K., Kevin, J. M., \& Dean, E. (1990). Preference between Salary or Job Security Increase. International Journal of Manpower, 11(7), 25-31.

Yusoff, W. F., Kian, T. S., \& Idris, M. T. (2013). Herzberg's Two-Factor Theory on work motivation: Does it works for today's environment? Global Journal of Commerce and Management Perspective, 2(5), 18-22.

Zarei, E., Zainalipour, H., Mohammadi, M., \& Zare, S. (2013). Scale construction and validation for evaluation of training performance in Hormozgan University of Medical Science. Journal of Applied Environmental and Biological Sciences, 3(12), 101-106. 